thousand words.

From its roots in microbiology, immunology became a highly metaphysical exercise 40 years into its life, as scientists began to question the cellular and molecular basis of the immune response to the thousands, if not millions, of antigens that might be encountered by the mammalian host. These metaphysical problems ushered in the golden age of immunology. In a mere 30 years, the cellular and structural basis of the immune response was clarified and the genetic mechanisms that made the diversity of the system possible were deciphered. That done, the central questions posed by immunologists have been answered. Rapid ossification of immunology might have been anticipated at the conclusion of this remarkable progress.

But this has not happened. Important issues of signal transduction and cellular activation have now been put forth and a huge family of adhesion molecules has come to light as cellular interactions in the immune system have been scrutinized. Immunology remains a very lively subject. Traffic from the laboratory bench to the bedside intensifies. It was perhaps brazen to have put this encyclopaedia between hard covers when a loose-leaf format, in which updated pages could replace outworn knowledge or add new information, might have been more viable. The editors assure us in the preface that this is not so. But immunology is not anatomy and only time will convert us to their conviction. $\square$

Fred S. Rosen is at the Center for Blood Research, Inc., 800 Huntington Avenue, Boston, Massachusetts 02115, USA.

\section{Laboratory manuals}

Immunoassay Automation: A Practical

Study Guide edited by D. W. Chan.

Academic, $\$ 49.50, £ 30.50$ (spirally bound).

- Techniques for the Analysis of Complex Genomes edited by R. Anand. Academic , $\$ 39.95$, £19.50 (spirally bound).

- Nonisotopic DNA Probe Techniques edited by L. J. Kricka. Academic, \$39.95 $£ 26.50$ (spirally bound).

GUS Protocols: Using the GUS Gene as a Reporter of Gene Expression edited by S. R. Gallagher. Academic, \$29.95, $£ 19.50$ (spirally bound).

- Baculovirus Expression Vectors: $A$ Laboratory Manual edited by D. R. O'Reilly, L. K. Miller and V. A. Luckow. W. H. Freeman, $\$ 49.95$ (spirally bound). - Gene Expression in Neural Tissues Nolume 9 of Methods in Neurosciences) edited by P. M. Conn. Academic, $\$ 49.95$, $£ 31$ (spirally bound), $\$ 95, £ 59$ (hard covers).

Virology: A Laboratory Manual by F. G. Burleson, T. M. Chambers and D. L. Weidbrauk. Academic, \$29.95, £18.95 (spirally bound).
Madness to
the method

John W. Galloway

Scientific Literacy and the Myth of the Scientific Method. By Henry $H$. Bauer. University of Illinois Press: 1992. Pp. 192. $\$ 24.95$.

HENRY Bauer has written a book to challenge current ideas about scientific literacy and demolish the myth of the scientific method, a concept that he claims was discarded decades ago by most historians and philosophers of science. Indeed, Peter Medawar pointed out the dangers of belief in the scientific method. For it is the professional business of scientists to solve problems; so those who claim to believe in the method but fail to solve a given problem must either not know the correct method, in which case they are incompetent, or simply be too idle to apply it. Bauer argues that strict adherence to the model of the scientific method leads not only to a stifling of creativity and to bad science, including deliberate fraud, but also to a misunderstanding of science in society.

Bauer begins by looking at how science or, in his words, its reputation works in our culture, exposing some popular fallacies about scientific literacy among the public. Promotion of scientific literacy is beginning to take on the appearance of a major industry, yet he believes that "things are drastically wrong with almost everything that has been said about the supposedly critical state of scientific literacy". He rubbishes the nonsensical rhetoric on the utilitarian value of such literacy, adding that it is no more than part of a public-relations exercise by scientists. There are perfectly good reasons for being scientifically literate, but they are not much different from the benefits of any sort of literacy. It is worth recalling that on learning that the Earth went around the Sun, Sherlock Holmes said that he couldn't see what possible use the knowledge could be to him and now that he knew it, he proposed to forget it. When individuals or organizations really need to know some science, they can become experts in it very quickly. And it is by no means certain that science would benefit if the public understood science better.

But Bauer has more specific concerns. What exactly is meant by scientific literacy? It might mean, as he points out, 'knowing' some science. But how much, and which bits? He notes that different sciences do not often resemble one another a great deal, and not just because of differences in subject matter.
One has only to think of the contrasting ways mathematics is used in theoretical physics and molecular biology (physics relies a great deal for its explanatory power on metaphor).

What's more, as Bauer points out, questions about science cannot easily be reduced to simplistic true-or-false or multiple-choice answers. Here he makes a useful distinction between the science we learn as fact ("textbook science") and the science that is new ("frontier science"), where research is continually creating more knowledge, much of it unreliable and subject to change, and where all fraud takes place. As he says, this division can cause problems for those who rely on the media for knowledge of their science: some people are disturbed to discover that science is just as evanescent as the rest of the news, particularly if they see science as being always dependable.

Certainly, as Bauer contends, it might be more useful for lay people to understand how science works rather than its results. For example, the mistaken but stereotypical view of science as a dispassionate, objective, systematic pursuit of knowledge means that science is perceived as self-regulatory, when in reality, Bauer argues, professional codes of ethics need to be established to deal with, say, cases of transgression. $\mathrm{He}$ emphasizes that science is a cooperative, continuously changing and complex enterprise carried out by fallible humans, a social activity or "game" that is an essential part of our cultural heritage; and that it will be of greater benefit to us and better understood when recognized as such.

Bauer develops his theme well, using the myth of method to illuminate many aspects of popular misconceptions about science. But he is better at saying what science is not, defining it by exclusion, than giving a clear idea about what makes it distinctive. Perhaps it is a mistake to look for any general definition of science. In this respect, his adoption of the old analogy between science and games is particularly apt - many games share features, but it is difficult to see what solitaire, chess and football have in common. So, too, with the sciences.

Science can be recognized, however, by the sort of questions it asks and the sort of methods it has to answer them. In the words of Neils Bohr, "it is the task of science to reduce deep truths to trivialities". A large part of scientific creativity is devising methods to do just that. It is by its methods, not its method, that science is known and recognized.

John W. Galloway is at the Nuffield Foundation, 28 Bedford Square, London WC1B 3EG, UK. 